\title{
Subclinical Hypo and Hyperthyroidism is Prevalent both in Pakistani and Afghani Population of Quetta City-Pakistan
}

\author{
Ruquia Abdul Wahid ${ }^{1}$, Mahrukh Naseem ${ }^{1 *}$, Asmatullah Kakar ${ }^{1}$, Zafarullah $^{1}$, Nayab Khan ${ }^{1}$, Muhammad Irfan Masood ${ }^{2}$ \\ ${ }^{1}$ Department of Zoology, University of Balochistan, Quetta-87300, Pakistan \\ ${ }^{2}$ Institute of Pharmaceutical Science, University of Veterinary and Animal Sciences, 54000, Lahore, Pakistan
}

DOI: $10.36348 /$ sijtcm.2020.v03i03.003

| Received: 22.02.2020 | Accepted: 01.03.2020 | Published: 27.03.2020

*Corresponding author: Mahrukh Naseem

\section{Abstract}

The thyroid gland is a major endocrine gland. Subclinical hypothyroidism and hyperthyroidism are common health issue particularly in the developing and if remain untreated can manifest serious health consequences. The aim of this study was to figure out the current situation of subclinical thyroid disease in the Pakistani and Afghan refugees living in Quetta city. For this purpose different public sector hospitals were visited on regular bases from October 2018 to October 2019 to find out the prevalence of this disease. Subclinical hypo and hyperthyroid patients of both the nationalities age among 20-70 years were enrolled. Furthermore, the prevalence of clinical sign and symptoms related to thyroidal dysfunction, the physical activities of the patients, use of iodized/non-iodized salt, feeding habit was also recorded. To confirm the status of hypothyroidism and hyperthyroidism the thyroid functional test (TFT) was performed by using Radio Immuno Assay (RIA). Our data showed that the prevalence of Thyroidism was higher in females than males both in Pakistani and Afghani patients. The overall prevalence of euthyroid was (21.66\%), hypothyroidism (45.83\%) and hyperthyroid $(32.52 \%)$, thus the prevalence of hypothyroidism was found to be higher than hyperthyroidism and this prevalence was high in the patients among 20-45 years of age. Furthermore, the prevalence data related to clinical sign showed that weight gain $(82.12 \%)$, cold intolerance $(79.60 \%)$ and anxiety $(74.34 \%)$ was more common in hypothyroid patients whereas, weight loss $(84.23 \%)$, goiter $(79.13 \%)$ and increase heart rate $(78.51 \%)$ were the common issues in hyperthyroid patients.

Keywords: Hyperthyroidism, Hypothyroidism, fT3, fT4, TSH, Pakistani, Afghan refugees.

Copyright @ 2020: This is an open-access article distributed under the terms of the Creative Commons Attribution license which permits unrestricted use, distribution, and reproduction in any medium for non-commercial use (NonCommercial, or CC-BY-NC) provided the original author and source are credited.

\section{INTRODUCTION}

Thyroid hormones are essential for the normal growth and development of all body tissues since it helps to regulate the functions of every cell including hepatocytes [1]. Hypothyroidism and hyperthyroidism are common hormonal disorders that have lifelong health adverse effects [2]. Proper screening and early treatment of thyroidal disease might be helpful to prevent fractures, osteoporosis, atrial fibrillation, growth depression, long term consequences associated with heart failure and risk of death [3-5]. However, proper screening, evaluation of optimum TSH level and management of subclinical thyroid disease is still controversial [6]. Subclinical hypothyroidism is a clinical condition when thyroid stimulating hormone (TSH) level is higher than normal value and free thyroxine (T3) \& triiodothyronine (T4) level remains within normal values [7]. Hypothyroidism is an autoimmune disorder, occurring either as primary atrophic hypothyroidism or/and maybe pituitary or hypothalamic syndromes that lead to secondary hypothyroidism [8]. The risk of hypothyroidism is very high in the individuals of old age particularly in women and prolonged subclinical hypothyroidism leads to overt hypothyroidism [9]. Nearly, $3-10 \%$ of the population is affected with hypothyroidism globally and the frequency is high in female [10]. Also in Pakistan, the prevalence of hypothyroidism cases is $2 \%$ higher than hyperthyroidism [11].

Subclinical hyperthyroidism is a clinical condition in which TSH level is very low than normal even sometimes undetectable and FT3 and FT4 remain into the normal range [12, 13]. Hyperthyroidism is commonly caused by Graves disorder primarily affects the young population,an extensive dose of L-thyroxine and toxic multinodular goiters affect the old people [11, $14]$. 
Iodine is a fundamental unit for the proper secretion of thyroid hormone and an imbalance of the iodine lead to the development of hypothyroid and hyperthyroid disorder. Iodine is available in food and water and if these sources are deficient with iodine leads to hypothyroidism, similarly, excessive iodine intake in the diet causes hyperthyroidism $[15,16]$. The objective of this study was to compare the prevalence, thyroid functional test (TFT), clinical sign and symptoms of subclinical hypothyroid and hyperthyroid patients of Pakistani and Afghan refugees living in Quetta city.

\section{MATERIALS AND METHODS}

The study was conducted from October 2018 to October 2019. In this study, subclinical hypothyroid and hyperthyroid (both Pakistani and Afghan refugees) patients of both genders age between 20-70 years were included. The complete history of the participants was recorded from their consultants. Patients. The individual having any other genetic disorder, hepatitis, AIDS, taking thyroxin therapy and pregnant women were excluded from the study. All the participants were interviewed by using a questionnaire to collect demographic information and disease data related to thyroidism. All the individuals were divided into the following groups:

- This group included euthyroid Pakistani (125 female; 116 male) and Afghani (97 female and 93 male) individuals and this group were considered as a normal group.

- This group includes hypothyroid Pakistani (306 female; 205 male) and Afghan refugees (246 female; 155 male) patients.

- This group comprises of hyperthyroid Pakistani (275 female; 150 male) and Afghani (100 female; 122 male) patients.

\section{Blood Sampling and Biochemical Analysis}

Under well-sterilized conditions, 5-7 $\mathrm{ml}$ of blood were collected through the vein of the patients. The serum was separated for further bio-chemical analysis. The subjects were clinically categorized into the euthyroid, subclinical hypothyroid and subclinical hyperthyroid state by performing TFT using Radio Immuno Assay by following the manufacture's protocol. The values for the TFT were compared with the normal ranges as described by [16] of TSH (0.3-5.0 $\mathrm{mIU} / \mathrm{l})$, fT3 (2.5-5.8 pmol/l) and for fT4 (11.5-23.0 $\mathrm{pmol} / \mathrm{l})$.

\section{STATISTICAL ANALYSIS}

Results are presented as Mean \pm SEM. Twoway repeated measure analysis of variance (ANOVA) was performed followed by post hoc Tukey's test by using GraphPad Prism (Version 6). Differences were considered significant at $\mathrm{P}<0.05$.

\section{RESULTS}

A total of 1990 cases of thyroidism were reported from different public hospitals of Quetta city. The overall prevalence of thyroidism was higher in females $57.74 \%(\mathrm{~N}=1,149 / 1990)$ than males $42.26 \%$ $(\mathrm{N}=841 / 1990)$ both in Pakistani and Afghani patients (Figure-1). The prevalence of euthyroid ( $\mathrm{N}=431 / 1990)$, subclinical hypothyroid ( $\mathrm{N}=912 / 1990)$ and hyperthyroid (N=647/1990) were 21.66, 45.83 and $32.52 \%$ respectively (Figure-2). Thus the prevalence of hypothyroid and hyperthyroid is found more likely in females.

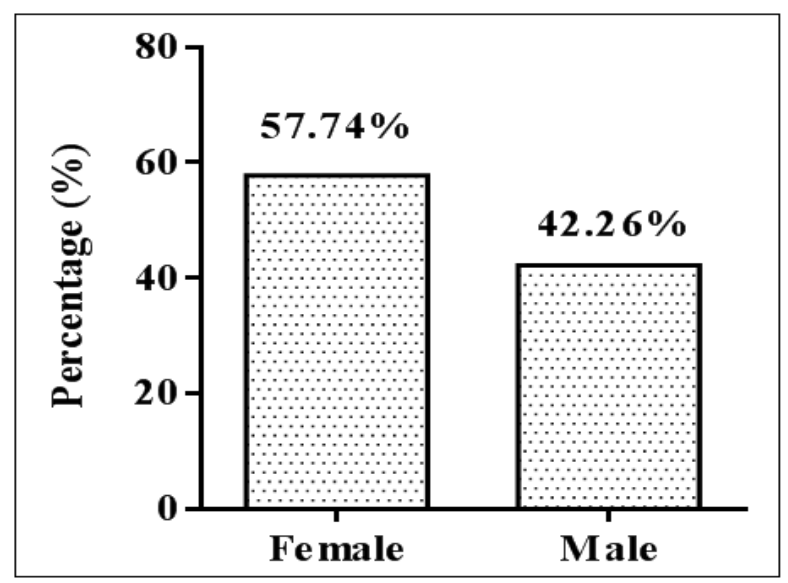

Fig-1: Gender wise prevalence of Thyroidism in the patients of Quetta city 


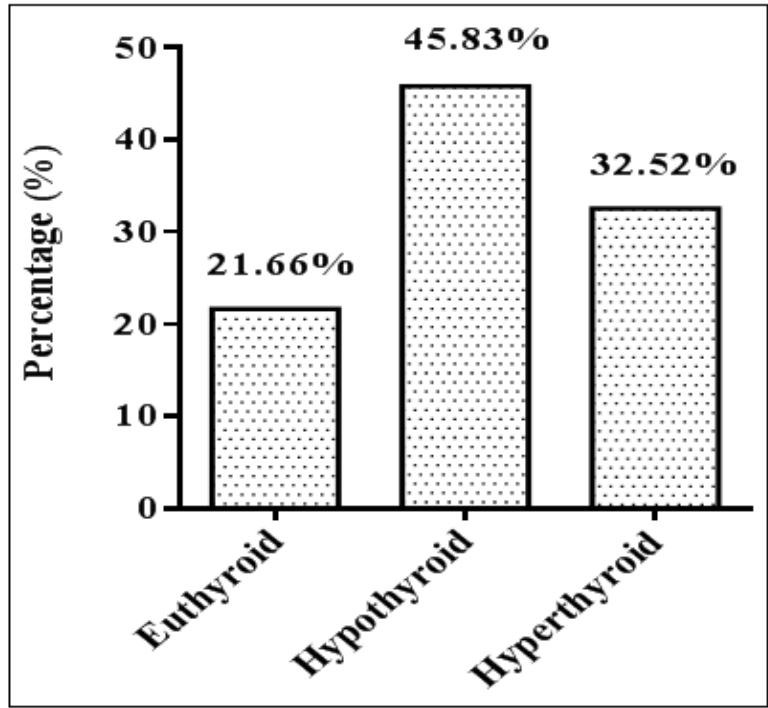

Fig-2: Overall prevalence of euthyroid, hypothyroid and hyperthyroid disease in the patients of Quetta city

Furthermore, the prevalence of both subclinical hypothyroid and hyperthyroid cases was high in Pakistani patients than Afghan refugees. In Pakistani patients, the incidence was found to be higher in hypothyroid females $(15.38 \%)$ and the least incidence was found in hyperthyroid male patients (7.54\%). However, in the case of Afghan refugees, the highest percentage was found in hypothyroid female patients $(12.36 \%)$ and least in hyperthyroid females $(5.03 \%)$ (Table-1).

Table-1: Prevalence (\%) of Euthyroid ( $\mathrm{N}=222$ females and $\mathrm{N}=209$ males), hypothyroidism (N=552 females and $\mathrm{N}=360$ males) and hyperthyroidism ( $=375$ females and $\mathrm{N}=272$ males) in Pakistani and Afghan Refugees patient of Quetta city

\begin{tabular}{|l|l|l|l|l|}
\hline Nationality & Gender & Euthyroid & Hypothyroid patients & Hyperthyroid patients \\
\hline \multirow{2}{*}{ Pakistani } & Female & $125(6.28 \%)$ & $306(15.38 \%)$ & $275(13.82 \%)$ \\
& & & & \\
\cline { 2 - 5 } & Male & $116(5.83 \%)$ & $205(10.30 \%)$ & $150(7.54 \%)$ \\
\hline \multirow{2}{*}{ Afghan Refugees } & Female & $97(4.87 \%)$ & $246(12.36 \%)$ & $100(5.03 \%)$ \\
\cline { 2 - 5 } & Male & $93(4.67 \%)$ & $155(7.79 \%)$ & $122(6.13 \%)$ \\
\hline
\end{tabular}

The prevalence of subclinicalhypothyroid and hyperthyroid was recorded higher in the age group 2045 years in both genders of Pakistani and Afghani patientsthan the patients of 46-70 years age group (Figure-3).

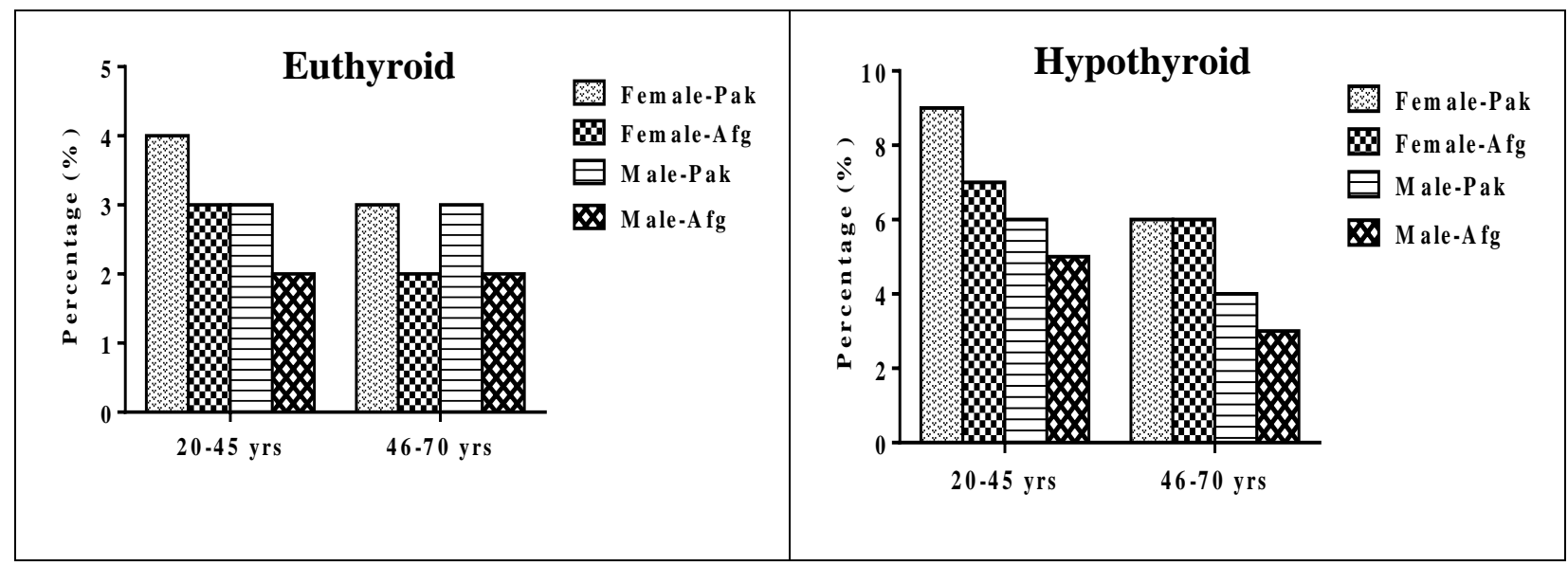




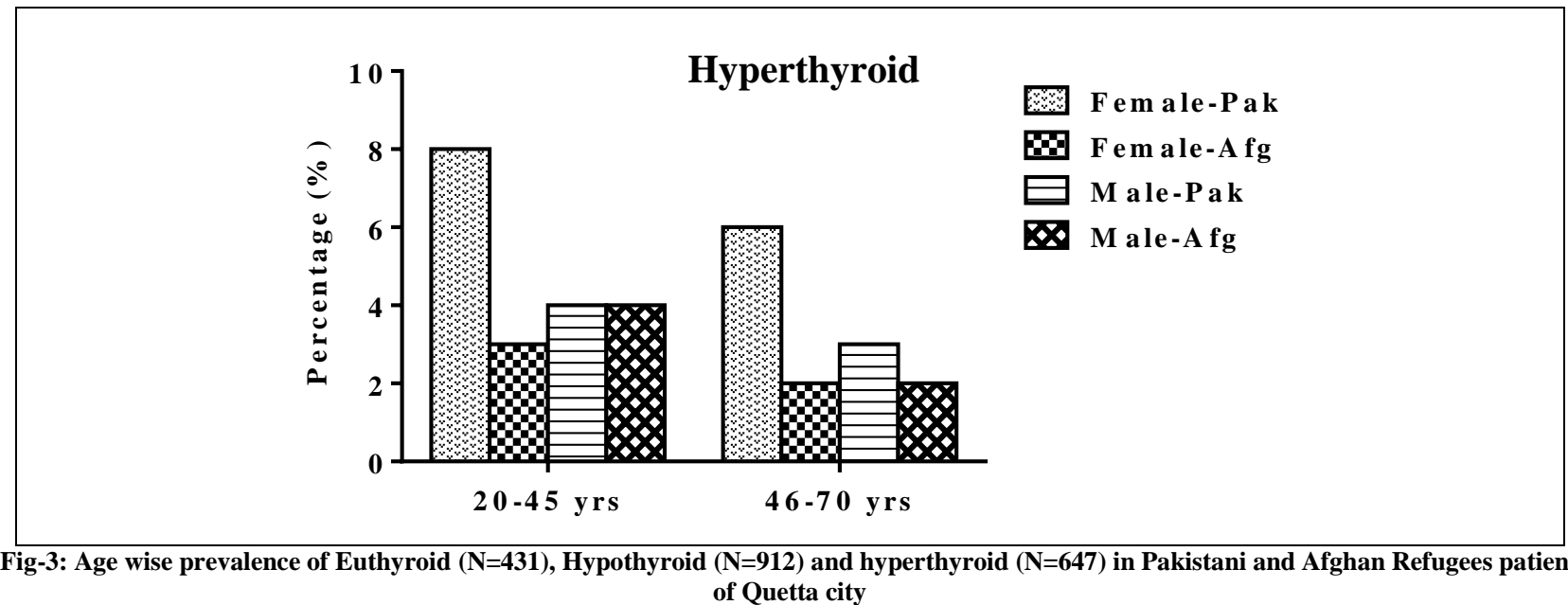

Table-2 represents the comparison of TFT (TSH, fT3, and fT4) of male, female Pakistani and Afghani individuals. The mean value of TSH was found to be significantly increased for hypothyroid and decreased for hyperthyroid patients in all the age groups. However, the serum level of fT3 was significantly increased only in hyperthyroid female (2045 age group) both in Pakistani and Afghani patients whereas, fT4 was significantly increased only in Pakistani hyperthyroid female (20-45 years of age) patients. The mean level of these two thyroid hormones was more significant in females than males.
Table- 3 is showing the demographic features of thyroid disease, it is found that thyroidal disease is high in the people living in the urban area, using noniodized salt, people with inactive lifestyle and mostly eating more meat. Furthermore, common clinical signs observed in subclinical hypothyroid patients were weight gain, cold intolerance, anxiety, muscular pain, depression, skin issues, and joint pain. Hyperthyroid patients commonly experienced weight loss, goiter (swelling at front of the neck), increase heart rate, fatigue, heat intolerance, shortness of breath, skin issues, depression gum infection, hair loss, and memory weak/loss (Table-4).

Table-2: Comparison of thyroid functional test (TFT) with clinical diagnosis in euthyroid, subclinical hypo and hyperthyroid patients

\begin{tabular}{|c|c|c|c|c|c|c|c|c|c|c|c|c|c|}
\hline \multirow[t]{2}{*}{ 㺼 } & \multirow[t]{2}{*}{ 色 } & \multicolumn{2}{|c|}{$\begin{array}{c}\text { Euthyroid } \\
\text { Pakistani } \\
\text { individuals } \\
(\mathbf{N}=\mathbf{2 4 1})\end{array}$} & \multicolumn{2}{|c|}{$\begin{array}{c}\text { Euthyroid } \\
\text { Afghani } \\
\text { individuals } \\
(\mathbf{N}=190)\end{array}$} & \multicolumn{2}{|c|}{$\begin{array}{c}\text { Subclinical } \\
\text { hypothyroid } \\
\text { Pakistani } \\
\text { patients } \\
(\mathbf{N}=511)\end{array}$} & \multicolumn{2}{|c|}{$\begin{array}{c}\text { Subclinical } \\
\text { hypothyroid } \\
\text { Afghani } \\
\text { patients } \\
(\mathrm{N}=401)\end{array}$} & \multicolumn{2}{|c|}{$\begin{array}{c}\text { Subclinical } \\
\text { hyperthyroid } \\
\text { Pakistani } \\
\text { patients } \\
(\mathrm{N}=425)\end{array}$} & \multicolumn{2}{|c|}{$\begin{array}{c}\text { Subclinical } \\
\text { hyperthyroid } \\
\text { Afghani } \\
\text { patients } \\
(\mathrm{N}=222)\end{array}$} \\
\hline & & $\begin{array}{c}20-45 \\
\text { yrs }\end{array}$ & $\begin{array}{c}46-70 \\
\text { yrs } \\
\end{array}$ & $\begin{array}{c}20-45 \\
\text { yrs } \\
\end{array}$ & $\begin{array}{c}46-70 \\
\text { yrs }\end{array}$ & $\begin{array}{c}20-45 \\
\text { yrs } \\
\end{array}$ & $\begin{array}{c}\text { 46- } \\
70 y r s\end{array}$ & $\begin{array}{c}20-45 \\
\text { yrs } \\
\end{array}$ & $\begin{array}{c}\text { 46-70 } \\
\text { yrs }\end{array}$ & $\begin{array}{c}20-45 \\
\text { yrs } \\
\end{array}$ & $\begin{array}{c}\text { 46-70 } \\
\text { yrs }\end{array}$ & $\begin{array}{c}20-45 \\
\text { yrs }\end{array}$ & $\begin{array}{c}46-70 \\
\text { yrs }\end{array}$ \\
\hline \multirow[t]{2}{*}{$\overrightarrow{0}$} & 胥 & & & & & $\begin{array}{c}29.16 \pm \\
0.80^{c}\end{array}$ & & $\begin{array}{c}29.78 \pm \\
0.73^{c}\end{array}$ & & $\begin{array}{c}0.56 \pm 0 \\
.01^{\mathrm{c}}\end{array}$ & & $\begin{array}{l}0.59 \pm \\
0.02^{c}\end{array}$ & $\begin{array}{l}0.59 \pm \\
0.04^{\mathrm{c}}\end{array}$ \\
\hline & $\frac{3}{2}$ & & $\begin{array}{c}2.81 \pm \\
0.16\end{array}$ & & & $\begin{array}{c}28.72 \pm \\
0.79^{\mathbf{c}}\end{array}$ & $\begin{array}{c}28.79 \pm \\
1.04^{\mathbf{c}} \\
\end{array}$ & $\begin{array}{c}28.74 \pm \\
0.92^{\mathrm{c}} \\
\end{array}$ & & $.01^{\mathrm{c}}$ & & & $\begin{array}{l}0.60 \pm \\
0.03^{\mathrm{c}}\end{array}$ \\
\hline \multirow{2}{*}{$\vec{\omega}$} & 包 & $\begin{array}{c}2.94 \pm \\
0.11\end{array}$ & $\begin{array}{c}2.94 \pm \\
0.12\end{array}$ & $\begin{array}{c}3.00 \pm \\
0.11\end{array}$ & & $\begin{array}{c}2.92 \pm 0 \\
.07\end{array}$ & $\begin{array}{c}2.91 \pm 0 \\
.07\end{array}$ & $\begin{array}{c}2.95 \pm 0 \\
.09\end{array}$ & $\begin{array}{c}2.98 \pm 0 \\
.08\end{array}$ & $\begin{array}{c}3.00 \pm 0 \\
.07^{\mathrm{a}}\end{array}$ & & $\begin{array}{l}3.08 \pm \\
0.10^{b}\end{array}$ & $\begin{array}{c}3.09 \pm \\
0.13\end{array}$ \\
\hline & $\frac{2}{2}$ & $\begin{array}{c}2.94 \pm \\
0.15 \\
\end{array}$ & $\begin{array}{c}2.93 \pm \\
0.19 \\
\end{array}$ & $\begin{array}{c}2.99 \pm \\
0.13 \\
\end{array}$ & $\begin{array}{c}3.01 \pm \\
0.13 \\
\end{array}$ & $\begin{array}{c}2.89 \pm 0 \\
.11 \\
\end{array}$ & $\begin{array}{c}2.88 \pm 0 \\
.13 \\
\end{array}$ & $\begin{array}{c}2.94 \pm 0 \\
.11 \\
\end{array}$ & $\begin{array}{c}2.95 \pm 0 \\
.10 \\
\end{array}$ & $\begin{array}{c}3.00 \pm 0 \\
.13 \\
\end{array}$ & $\begin{array}{c}2.99 \pm \\
0.11 \\
\end{array}$ & $\begin{array}{l}3.07 \pm \\
0.11^{\mathrm{a}} \\
\end{array}$ & $\begin{array}{c}3.06 \pm \\
0.11\end{array}$ \\
\hline \multirow[t]{2}{*}{$\vec{B}$} & 里 & $\begin{array}{l}17.60 \\
\pm 0.65\end{array}$ & $\begin{array}{l}17.47 \\
\pm 0.65\end{array}$ & $\begin{array}{l}17.01 \\
\pm 0.59\end{array}$ & $\begin{array}{l}17.16 \\
\pm 0.60\end{array}$ & $\begin{array}{c}17.45 \pm \\
0.28\end{array}$ & $\begin{array}{c}17.29 \pm \\
0.34\end{array}$ & $\begin{array}{c}17.00 \pm \\
0.30\end{array}$ & $\begin{array}{c}17.17 \pm \\
0.27\end{array}$ & $\begin{array}{c}17.80 \pm \\
0.37^{\mathrm{a}}\end{array}$ & $\begin{array}{l}17.71 \\
\pm 0.36\end{array}$ & $\begin{array}{l}17.25 \\
\pm 0.61\end{array}$ & $\begin{array}{l}17.15 \\
\pm 0.68\end{array}$ \\
\hline & $\frac{3}{2}$ & $\begin{array}{l}17.26 \\
\pm 0.50 \\
\end{array}$ & $\begin{array}{l}17.50 \\
\pm 0.56 \\
\end{array}$ & $\begin{array}{l}17.11 \\
\pm 0.54 \\
\end{array}$ & $\begin{array}{l}17.12 \\
\pm 0.64 \\
\end{array}$ & $\begin{array}{c}17.24 \pm \\
0.25 \\
\end{array}$ & $\begin{array}{c}17.46 \pm \\
0.30 \\
\end{array}$ & $\begin{array}{c}16.96 \pm \\
0.30 \\
\end{array}$ & $\begin{array}{c}16.99 \pm \\
0.34 \\
\end{array}$ & $\begin{array}{c}17.46 \pm \\
0.40 \\
\end{array}$ & $\begin{array}{l}17.37 \\
\pm 0.46 \\
\end{array}$ & $\begin{array}{l}17.27 \\
\pm 0.47 \\
\end{array}$ & $\begin{array}{l}17.16 \\
\pm 0.54 \\
\end{array}$ \\
\hline
\end{tabular}

Data is presented asmean \pm SEM in Pakistani and Afghani euthyroid VS thyroid patients. $a=P<0.05$, $\mathrm{b}=\mathrm{P}<0.001$ and $\mathrm{c}=\mathrm{P}<0.0001$. 
Table-3: Demographic features and Dietary habit of subclinical hypo and hyperthyroidism

\begin{tabular}{|c|c|c|c|c|}
\hline Features & Subclinical hyp & $(\mathrm{N}=912)$ & Subclinical hype & $(\mathrm{N}=647)$ \\
\hline Location & No. of cases & \%age & No. of cases & $\%$ age \\
\hline Urban & 518 & 56.80 & 465 & 71.87 \\
\hline Rural & 394 & 43.20 & 182 & 28.13 \\
\hline Maternal status & & & & \\
\hline Married & 602 & 66.00 & 459 & 70.94 \\
\hline Unmarried & 310 & 34.00 & 188 & 29.06 \\
\hline Salt utilization & & & & \\
\hline Non-Iodized salt & 473 & 51.87 & 399 & 61.67 \\
\hline Iodized salt & 439 & 48.13 & 248 & 38.33 \\
\hline Life style & & & & \\
\hline Sedentary & 629 & 68.97 & 519 & 80.22 \\
\hline Active & 283 & 31.03 & 128 & 19.78 \\
\hline Feeding habit & & & & \\
\hline Veg & 868 & 95.17 & 588 & 90.88 \\
\hline Non-Veg & 44 & 4.82 & 59 & 9.12 \\
\hline Meat intake & & & & \\
\hline Meat & 900 & 98.68 & 612 & 94.59 \\
\hline No meat & 12 & 1.31 & 35 & 5.41 \\
\hline
\end{tabular}

Table-4: Clinical features associated with subclinical hypothyroidism and hyperthyroidism

\begin{tabular}{|c|c|c|c|c|}
\hline \multirow{2}{*}{ Clinical features/signs } & \multicolumn{2}{|c|}{ Subclinical hypothyroid (N=912) } & \multicolumn{2}{c|}{ Subclinical hyperthyroid (N=647) } \\
\cline { 2 - 5 } & No. of cases & \%age & No. of cases & \%age \\
\hline Weight gain & 749 & 82.12 & 45 & 6.95 \\
\hline Weight loss & 81 & 8.88 & 545 & 84.23 \\
\hline Gum diseases & 215 & 23.57 & 399 & 71.66 \\
\hline Swelling at front of neck (Goiter) & 259 & 28.39 & 512 & 65.68 \\
\hline Skin issues & 547 & 59.97 & 425 & 37.55 \\
\hline Anxiety & 678 & 74.34 & 243 & 63.52 \\
\hline Depression & 555 & 60.85 & 411 & 58.57 \\
\hline Hair loss & 292 & 32.01 & 379 & 40.49 \\
\hline Menstrual irregularities & 401 & 43.96 & 262 & 37.24 \\
\hline Chronic Renal failure & 205 & 22.47 & 241 & - \\
\hline Hoarseness & 431 & 47.25 & - & 29.52 \\
\hline Nervousness & 329 & 36.07 & 191 & 51.31 \\
\hline Memory weak/ loss & 471 & 51.64 & 332 & 24.88 \\
\hline Infertility & 213 & 23.35 & 161 & 33.84 \\
\hline Cardiovascular problems & 499 & 54.71 & 219 & 76.50 \\
\hline Fatigue & 274 & 30.04 & 495 & 23.02 \\
\hline Joint pain & 519 & 56.90 & 149 & 49.30 \\
\hline Muscular pain & 614 & 67.32 & 319 & 72.79 \\
\hline Heat intolerance & - & - & 471 & - \\
\hline Cold intolerance & 726 & 79.60 & - & 78.51 \\
\hline Increase heart rate & 189 & 20.72 & 508 & 72.17 \\
\hline Shortness of breath & 148 & 16.22 & 467 & 387 \\
\hline
\end{tabular}

\section{DISCUSSION}

The thyroid hormone irrationalities may vary from subclinical cases which is asymptomatic with abnormal TSH level but normal FT3 and FT4 blood levels to symptomatic stages with abnormalities in FT3 and FT4 along with TSH levels [17]. Since the thyroid is the burning health issue so, the present study was conducted to investigate the prevalence, biochemical and clinical manifestation associated withage, gender and Nationality (Pakistani and Afghani) of the subclinical hypothyroid and subclinical hyperthyroid population living in Quetta City. Our results clearly showed that Thyroidism is high in females as compared to male. The results are in agreement with others $[5,11$, 18]. Previously, the same findings were reported from various parts of the Balochistan, but they did not make any comparison among Pakistani and Afghan refugees [19]. Previously it was reported that the prevalence of subclinical hyperthyroidism $(5.8 \%)$ is higher than subclinical hypothyroidism $(5.4 \%)$ [15]. But we found that the prevalence of subclinical hypothyroidism 
$(45.83 \%)$ was higher than subclinical hyperthyroidism $(32.51 \%)$ because Quetta is a hilly area and iodine deficiency is the major problem. However, many researchers reported a high prevalence of hypothyroidism than hyperthyroidism [18, 20, 21]. Iodine deficiency is a leading cause of thyroid diseases. As we found that the majority of the patients were utilizing non-iodized salt, particularly in the rural areas where majority people have a misconception regarding iodized salt. Approximately $70 \%$ population in Pakistan are suffering from the problem related to iodine deficiency [19] and thyroid is the most frequent health issue in the hilly areas [18].

Our results reflected that the prevalence of Thyroidism was high in younger individuals (20-40 years of age). Many studies revealed the high prevalence of Thyroidism was found to occur more frequently in this age group [16, 22]. Furthermore, in Pakistan, the female is more likely to be affected with hypothyroid than males and most frequently developed in the adult age between 20-35 years [23, 24]. The high ratio of Thyroidism in adults maybe because of the reproduction ability and hyperactivity of reproductive hormones [22]. Iodine deficiency is one of the fundamental reasons for the high ratio of Thyroidism, particularly in South Asian countries. About one-third, part of the world prevails in the iodine deficiency problem [25].

We diagnosed the thyroid dysfunction by analyzing TFT, as thyroid diseases depend upon the blood levels of TSH, fT3, and fT4. TSH is the most important biomarker to determine the function of the thyroid gland [11]. However thyroidal disease also depends upon various risk factors and geographical area variation with iodine status. Our results of TFT for subclinical hypo and hyperthyroidism are inconsistency with the finding of other researchers [16, 26, 27].

In hypothyroidism weight gain, weakness, dry skin, cold intolerance, depression, anxiety, hoarseness, cardiovascular disease, goiter, hair loss are the most common problems [16, 28], similarly, in hyperthyroidism weight loss, heat intolerance, depression, fatigue, high palpitations, shortness of breath, muscle weakness, etc are common clinical symptoms [13], as also found in our study.

\section{CONCLUSION}

We reported that Thyroidism was more common in female than in the male population both in the Pakistani as well as in the Afghan refugees living in Quetta city. Furthermore, the prevalence of hypothyroidism is high than hyperthyroidism particularly in the young to middle age females. However, the clinical symptoms were worst in Afghani patients due to a lack of awareness. General public awareness regarding dietary iodine consumption is necessary for this important geographical area to overcome the prevalence of the thyroidal disease in the population of Quetta city.

\section{REFRENCESS}

1. Liu, G., Liang, L., Bray, G. A., Qi, L., Hu, F. B., Rood, J., ... \& Sun, Q. (2017). Thyroid hormones and changes in body weight and metabolic parameters in response to weight loss diets: the pounds lost trial. International journal of obesity, 41(6), 878-886.

2. Ullah, A. (2013). Subclinical hypothyroidism and hyperthyroidism in patients with congestive heart failure. Khyber Medical University Journal, 5(3), 137-140.

3. Williams, G. R., \& Bassett, J. H. D. (2018). Thyroid diseases and bone health. Journal of endocrinological investigation, 41(1), 99-109.

4. Helfand, M. (2004). Screening for subclinical thyroid dysfunction in nonpregnant adults: a summary of the evidence for the US Preventive Services Task Force. Annals of internal medicine, 140(2), 128-141.

5. Yousaf, M., Shah, J., \& Jan, M. R. (2017). Frequency of thyroid dysfunctions in general population of Peshawar city and its association with serum alanine transaminase level. Isra Med $J, 9(2), 84-87$.

6. Biondi, B., \& Cooper, D. S. (2008). The clinical significance of subclinical thyroid dysfunction. Endocrine reviews, 29(1), 76-131.

7. Cooper, D. S. (2001). Subclinical hypothyroidism. New England Journal of Medicine, 345(4), 260-265.

8. Taylor, P. N., Albrecht, D., Scholz, A., GutierrezBuey, G., Lazarus, J. H., Dayan, C. M., \& Okosieme, O. E. (2018). Global epidemiology of hyperthyroidism and hypothyroidism. Nature Reviews Endocrinology, 14(5), 301.

9. Biondi, B., Cappola, A. R., \& Cooper, D. S. (2019). Subclinical hypothyroidism: a review. Jama, 322(2), 153-160.

10. Mubarak, B., Ashraf, S., \& Aslam, R. (2019). Determination of Serum Thyroid Hormones and Electrolytes in Hypothyroid and Hyperthyroid Females-A Case Control Study in Lahore, Pakistan. Turkish Journal of Endocrinology and Metabolism, 23(1), 19.

11. Attaullah, S., Haq, B. S., \& Muska, M. (2016). Thyroid dysfunction in khyber pakhtunkhwa, pakistan. Pakistan journal of medical sciences, 32(1), 111.

12. Kim, Y. A., \& Park, Y. J. (2014). Prevalence and risk factors of subclinical thyroid disease. Endocrinology and Metabolism,29(1), 20-29.

13. Biondi, B., \& Cooper, D. S. (2018). Subclinical hyperthyroidism. New England Journal of Medicine, 378:2411-9.

14. Patricia, W. (2008). Diabetes and thyroid disease. Clinical Diabetes, 18:111-118. 
15. Alam Khan, V., Khan, M. A., \& Akhtar, S. (2002). Thyroid disorders, etiology and prevalence. $J$ Med Sci, 2(2), 89-94.

16. Iqbal, M. A., Naseem, Z., Qureshy, A., Shahid, A., \& Roohi, N. (2016). Prevalence and Manifestations of Thyroidal Dysfunction in Central Punjab Pakistan (A Case Study). Sci. Int, 28(4), 3959-3963.

17. Unnikrishnan, A. G., \& Menon, U. V. (2011). Thyroid disorders in India: An epidemiological perspective. Indian journal of endocrinology and metabolism, 15(Suppl2), S78.

18. Kazmi, N. H. S., Gillani, S., Rauf, A., Zaman, H., Najeeb, S., \& Ahmad, I. (2018). Pattern of thyroid disorders among patients in hazara division, pakistan. Gomal Journal of Medical Sciences, 16(2).

19. Manzoor, H., Ahmad, H. K., Shuja, J., Gill, O. Q., Ali, A., Ahmad, M., ... \& Mahmood, Z. (2013). Association of Hypothyroidism \& Hyperthyroidism with Age and Gender in Balochistan, CENAR Quetta. Annals of Punjab Medical College (APMC), 7(1), 45-51.

20. Baral, N., Lamsal, M., Koner, B. C., \& Koirala, S. (2002). Thyroid dysfunction in eastern Nepal. Southeast Asian journal of tropical medicine and public health, 33(3), 638-641.

21. Aryal, M., Gyawali, P., Rajbhandari, N., Aryal, P., \& Pandeya, D. R. (2010). A prevalence of thyroid dysfunction in Kathmandu University Hospital, Nepal. Biomed Research, 21:411-415.

22. Pandey, R., Jaiswal, S., Sah, J. P., Bastola, K., \& Dulal, S. (2013). Assessment of serum enzymes level in patients with thyroid alteration attending manipal teaching hospital, Pokhara. Thyroid, 10, 12.

23. Ahmed, O. M., El-Gareib, A. W., El-Bakry, A. M., El-Tawab, S. A., \& Ahmed, R. G. (2008). Thyroid hormones states and brain development interactions. International Journal of Developmental Neuroscience, 26(2), 147-209.

24. Humerah, S., Siddiqui, A., \& Khan, H. F. (2016). Pattern of altered lipid profile in patients with subclinical and clinical hypothyroidism and its correlation with body mass index. Journal of the College of Physicians and Surgeons Pakistan, 26:463-466.

25. Zimmermann, M. B. (2014). Iodine deficiency and thyroid nodules. Nature Reviews Endocrinology. 10:707-8.

26. Roberts, L., McCahon, D., Johnson, O., Haque, M. S., Parle, J., \& Hobbs, F. R. (2018). Stability of thyroid function in older adults: the Birmingham Elderly Thyroid Study. Br J Gen Pract, 68(675), e718-e726.

27. Dinauer, C. A. (2019). The Value of ThyroidFunction Testing in the Pediatric Inpatient Setting Is Low. Clinical Thyroidology, 31(2), 52-54.

28. Zhang, Y., Wei, F., Zhang, J., Hao, L., Jiang, J., Dang, L., ... \& Jiang, L. (2017). Bisphenol A and estrogen induce proliferation of human thyroid tumor cells via an estrogen-receptor-dependent pathway. Archives of biochemistry and biophysics, 633, 29-39. 